\title{
The European Union as Trade Actor and Environmental Activist: Contradictory Roles?
}

\author{
Charlotte Bretherton \\ Liverpool John M oores University \\ John Vogler \\ Liverpool John Moores University
}

\begin{abstract}
The European Union has increasigly become an actor in its own right in the politics of the international economy. By virtue of its Common Commercial Policy it has always been a formidable trade policy actor, but over the last twen ty years the EC has also devel oped extensive environmental policy competences and the Union has aspired to a leadership role in negotiations on global sus tainability. This article describes the complex and multifaceted character of the EU as an external trade and environmental policy actor. It then considers cases where the two roles complement or contradict each other including; the Committee on Trade and Environment of the WTO, the Basel Convention, 'leghold traps', and the Biosafety Protocol for genetically modi fied organisms. The article concludes that, while disputes within the Union tend to be resolved in favour of trade interests, policy on the latter has been significantly influ enced by the Union's newer concern with environmental sustainability. (JEL
\end{abstract}

\footnotetext{
* Correspondence Address: Sohool of Social Science, Liverpool John M oores University, Henry Cotton Campus, 15-21 Webster Street, Liverpool, L3 2ET, England. (Tel) +44-151-231-4043, (F ax) +44-151-231-4359, (E-mail) c.a. bretherton@livjm.ac.uk (C2000 - Center for International E conomics, Sejong Institution. All rights reserved.
} 
Classifications: F13) \Key Words: European U nion, trade/ environment, competences, World Trade Oganization, international actors.>

\section{Introduction}

The European Union is the world's largest trading bloc. The sheer size of its market gives it incomparable influence on international trade issues (FCO/DTI, [1996]:18).

The Union has, on various occasions, confirmed its leading role in the (environmental) field where it is particularly well placed for taking the leadership in international negotiations in order to reconcile conflicting interests (European Commission, [1997]a:29).

The European Union attempts to reconcile, and even exploit, its position as the world's largest trading bloc - with a growing aspiration to exercise environmental policy leadership. This paper investigates the success of this enterprise by reviewing the EU contribution to the 'greening' of the world trade regime. The concept of a world trade regime as used here does not merely denote the GATT-WTO system but a wider understanding of all those principles, norms, rules and procedures that are relevant. In formal terms this means the inclusion of the Basel Convention and the Convention on Trade in Endangered Species (CITES) amongst other specific agreements regulating the exchange of goods and services across frontiers. It should also comprehend developing understandings concerning the relationship between trade and sustainable development, the purposes and environmental implications of trade norms and the desirability and possibility of regulation - in short the subject matter of the contemporary trade/ environment debate.

Our focus is upon the Union as a trade/ environment policy actor on the global stage, and our assumption is that the $E U$ is capable of purposive action in creating and reconciling, or failing to reconcile, its various roles. This approach derives from a larger work (Bretherton \& Vogler, [1999]) which considers a wider range of policy areas. ${ }^{1} \mathrm{~F}$ rom this we concluded that

1. The perceptions and expectations of third parties who interact with the EU was a major focus of the research for this study We gratefully acknowledge the generosity 
the interaction between internal and external expectations and demands concerning EU 'actorness' can usefully be characterised as a process of structuration. Such a process, as we shall see, has been particularly evident in the symbiotic inter relationship between the EU's external personality as a trade actor and the evolution of the GATT trade regime.

At the same time, the EU's internal Single $M$ arket and common environmental policies provide, in themselves, a model for the development of a trading regime between (formerly) separate national economies. This internal experience will necessarily inform external policy; moreover the EU has assiduously promoted its own model of regional cooperation. ${ }^{2}$ The Single $M$ arket experience may even, it will be argued, provide pointers towards potential strategies for coping with cur rent dilemmas over the appropriate relationship between trade regulation and environmental protection. Thus, in one respect the $\mathrm{EU}$ is an international actor and, in another, an exemplar.

This is not to say that the EU has somehow solved the trade/ environment problem. Its approach to the world trade regime has not always been consistent; moreover it has reflected in full measure the internal complexities of the B russels system. There is some evidence of enlightened leadership in the greening of the trade regime; but also of the pre-eminence of trade interests - as exemplified by the celebrated Tuna-D olphin case and, in particular, by the long-running saga of leghold traps. The record, in terms of the EU's trade and environmental roles, is considered below. First, however, the claim that the EU constitutes an international actor - in these and other policy areas - requires examination.

of the many external M ission staff and NGO representatives who spared time to talk with us, and whose insights proved invaluable. We are deeply indebted, also, to the officials interviewed at the European Commission and the General-Secretariat of the Council of M inisters, the UK Foreign Office and Department of the Environment. Interviews took place (intermittently!) between January 1996 and December 1998. All information was provided in confidence and hence cannot be attributed to specific sources.

2. The EU proclaims itself to be 'a natural supporter of regional cooperation initiatives' (ACP-EC Development Finance Cooperation Committee, [1997]:23) It has consistently encouraged regional initiatives in Southern Africa, Latin America and elsewhere. 


\section{The EU as an International Actor}

The Union is very much more than a trading bloc but evidently, also, less than a sovereign state. The comparison is often made, and political arguments conducted, by reference to the template of the Westphalian state. In our view this merely obstructs a proper understanding of how the EU as an entity functions in the global system. Hence, in common with the International Lawyers, we treat the EU as an actor sui generis, focusing our attention upon the processes by which actorness is constructed in the various policy areas where the EU acts externally. This approach allows us to capture the complexity of the EU's external personality or, in Ruggie's terms ([1993]:172), to conceive of the EU as a 'multiperspectival polity'. Here, a further, important reason for examining the extent and characteristics of EU actorness is introduced - in that it differs quite considerably between the trade and environment sectors. As we shall see, this has significant consequences when the two intersect in external policy.

The external activities of the EU have developed considerably since 1958. In a number of cases, including environmental policy, the EU's role was not envisaged in the founding Treaties but has evolved in response to a range of internal and external factors. These fall into three broad categories - presence, opportunity and capability - all of which have considerable relevance to the EU's trade and environment roles.

Presence, broadly following Allen \& Smith [1990], refers to the ability to exert influence; to shape the perceptions and expectations of others. Presence does not connote purposive external action, rather it is a consequence of internal policies and processes. The economic presence of the EU, exemplified by the magnetic effect of the Single $M$ arket, provides the most obvious example. However the external impacts of the Common Agricultural Policy (CAP) and, indeed, the Common Fisheries Policy, also have significance; as does the EU's environmental presence, which reflects its status among the largest polluters and resource exploiters on earth.

Simply put, presence denotes latent actorness. It can also promote actorness, in that presence may generate responses from third parties which, in turn, produce demands for action by the EU. Thus, for example, 'environmental presence' as the world's second largest emitter of carbon dioxide 
has generated expectations of coherent action by the $E U$ in the sphere of global environmental politics. The ability to convert presence into actorness, however, is a function both of opportunity and capability.

Opportunity refers to the external environment of ideas and events which contextualise (promote/ constrain) EU actorness. Since the ending of the Cold War the policy environment, with its insistent rhetoric of globalization, has been conducive to EU actorness - not least in response to the many demands emanating from the former Eastern bloc. Of particular significance, in addition to the establishment of diplomatic relations, was formal recognition of the EU by Russia and other successor states. Recognition is an essential prerequisite for participation in the international (inter-state) system which, as we shall see, is not automatically available to the EU. $M$ oreover it varies considerably between policy sectors - not least trade and environmental policy - reflecting both external perceptions and preferences and internal capability.

Space does not permit us to discuss the various facets of and requirements for actor capability. Hence our focus, below, is upon two aspects which are particularly significant for an understanding of the trade/ environment relationship in EU external policy -

The ability to identify policy priorities and to formulate and pursue coherent policies.

The ability effectively to negotiate with other actors in the international sys tem.

The ability to formulate coherent policies varies considerably according to issue area. As in any complex decision-making system, divergent interests generate tensions over the prioritization of goals. However policy coordination within the $\mathrm{EU}$ is affected by difficulties which flow from its unique character - which are commonly refer red to as the problems of coherence and consistency.

Coherence refers to the internal policy processes of the EU - particularly, in the present context, the extent to which the capability exists to achieve a coordinated approach to trade and environment policy. While tensions between these policy areas are endemic in national political systems, the EU system demonstrates particular problems in this respect. These include the 
fragmentation of external policy due to the allocation of relevant portfolios to several Commissioners, and related frictions between Commissioners and officials of Directorates-General (DGs) at all levels. This problem is greatly exacerbated by the absence of a satisfactory mechanism to resolve disputes between Commissioners. In consequence, when trade/ environment disputes arise, the Environment Commissioner (supported by the relatively small staff of DGXI) is obliged to argue her case against the Trade Commissioner and the cohorts of high profile market openers at DGI.

Consistency denotes the extent to which the bilateral external policies of $M$ ember States are consistent with each other, and complementary to those of the EU. Hence consistency is a measure both of M ember State political commitment to common policies and the overall impact of the $\mathrm{EU}$ and its M ember States. In most aspects of trade policy, where there is full Community competence and common policies are entrenched, consistency is not a major problem. Nevertheless differences of interest between $\mathrm{M} \mathrm{ember}$ States become very evident during discussion of trade in 'sensitive' goods. ${ }^{3}$

In the case of environmental policy, problems of consistency are much more significant. Due to the absence of a firm Treaty basis for external environmental policy, Community competence in this area has developed incrementally and with only reluctant acquiescence by M ember States. In many areas of environmental policy, competence is shared or remains firmly with the M ember States. This lack of clarity is exacerbated by the sensitivity of related policy areas (not least energy and taxation policy), which ensures that there are significant differences of interest among $\mathrm{M}$ ember States. In crude terms these reflect degree of commitment to 'green' issues and level of economic development - the most evident division lying between the Scandinavians, Germans and Dutch (the 'environmental leaders') and the Southern Europeans. Inevitably there are also divisions which are less clearly discernible, particularly by third parties, and which reflect the complex bargaining processes that characterise the EU policy system. Thus differences between $\mathrm{M}$ ember States can be reflected in unpredictable ways

3. When giving examples, Portuguese 'sensitivity' concerning textiles is frequently cited However the Dutch government has shown 'sensitivity' over cut flowers and the German government over steel and even potatoes.... 
and in unrelated policy areas. Issue linkage is common, but difficult for third parties to identify. As a representative of an external M ission explained -

In negotiating with the EU one has to find out which country is obstructing progress and work on them. There is a problem of pinpointing which EU mem ber is opposing - countries may, for example, veto an issue as a bargaining chip related to some other concern. Also M ember States blame each other... (Inter view, Brussels, [1997])

These and other difficulties were frequently identified by third party negotiators. They are indicative of a perception of the EU - or more properly the EC personified by the European Commission - as a formidable negotiating partner. ${ }^{4}$ The ability to negotiate effectively is, of course, the second element of actor capability identified above - and, again, this varies considerably between the two policy areas under consideration.

In those areas where exclusive Community competence pertains (which are relatively few in the environmental sector) the European Community (but not the Union) enjoys international legal status, or personality. This provides a formal right of entry to the international system. In these cases, the Commission is the sole negotiator, albeit on a Council mandate. The process of agreeing the mandate frequently involves conflicts between $M$ ember States in the Council and tends to leave Commission negotiators with little room for manoeuvre. While this structural inflexibility can be prejudicial to effective negotiation, in practice it is used by the Commission as a negotiating ploy. Thus typical perceptions of the Commission's approach among third party representatives were - 'we've cooked up a deal, take it or leave it'; 'If you want one word different we'll have to go back to the Council'. E ven among representatives of large third countries there was a sense

4. Our actor's various names reflect its multifaceted character European Union (since 1993) is an overarching title referring to all three Pillars of the European construction - the European Community (Pillar I); Common Foreign and Security Policy (PilIar II); and J ustice and Home Affairs (Pillar III). Only the Community enjoys legal personality in international law, and within Pillar I the European Commission has sole right of policy initiative and of negotiation with third parties. Voting in the Council of $\mathrm{M}$ inisters is frequently by qualified majority. 
of the Commission as a formidable negotiating partner - 'there are no free lunches'(Interview material, B russels M issions, [ 1997]).

In environmental areas, where $\mathrm{M}$ ember States have been reluctant to transfer competence to the Community, the situation is very different. Here competence is frequently mixed (shared between the Community and the M ember States), disputed or unclear. This provides the opportunity for third parties to raise objections to participation by the EC/EU or to withhold recognition of the right of the Commission or the Presidency to negotiate on behalf of the $\mathrm{M}$ ember States - for example the Latin American regional group, M ercosur, objects to the special, 'discriminatory' treatment of the $E U$ in international fora. The relatively precarious status of the $E C / E U$ in environmental negotiations is compounded by the additional complexities of conducting a 'mixed' negotiation, where competence is shared; or by the lack of permanence and/ or expertise of the Presidency in circumstances for example climate change negotiations - where there is no Community competence and the Presidency speaks for the Union. Nevertheless even these difficulties can sometimes be turned to advantage, as one member of an EC delegation at recent negotiations put it -

N egotiation is a three card game. We don't tell third parties which articles are cover ed by Community competence and which by M ember States'. ( Inter view, DGXI [1996]).

The EU, we have argued, is a complex, multifaceted actor - perhaps a series of actors according to policy area. This is particularly evident from a consideration of the very different, and potentially contradictory, roles of the EC/ EU in trade and environmental policy.

\section{EU Trade and Environment Roles Compared}

First and foremost the Union has developed as a trade actor. Although much attention has been paid to the attempt to create a Common Foreign and Security Policy (CFSP), this should not obscure the real significance of the $\mathrm{EC} / \mathrm{EU}$ in the global system, which is grounded in trade. Trade provides the primary explanation for the accreditation of $164 \mathrm{M}$ issions to the EU and indeed the only 'muscle' currently available to the CFSP. Trade is 
the basis upon which the EU has developed a repertoire of external policy roles (Commission officials often speak of multifaceted relations with third parties as 'trade plus'). It was the creation of a customs union and the elaboration of a Common Commercial Policy (CCP) in the 1958 EEC Treaty that first necessitated the adoption of a common stance and a single negotiator in trade relations with the outside world. Since then the scale and integration of the internal market has grown apace both through enlargement, the trade creating effects of a customs union and the '1992 process' of completing the single market.

The creation of a customs union and the setting of a Common Commercial Tariff (CCT) necessarily involved the granting of competence to the Commission to negotiate tariff levels with third parties under the Common Commercial Policy, which has been effective since 1961. At that time the Community, in the shape of the Commission, was almost immediately involved in developing its role as a trade actor, as its trading partners sought to negotiate on the effects of the customs union. The GATT 'Dillon Round' of 1960-1 was largely devoted to this. ${ }^{5}$

The original Common Commercial Policy of the EC was something of a tabla rasa. I ts development, and the understandings and practices adopted by the Community as it emerged as a trade actor, very much the outcome of a mutual process of structuration. That is to say EU agency was constructed in terms of the disciplines and institutional setting of the GATT regime, but equally the regime itself was moulded to the requirements of one of its most powerful participants. (Of primary significance here is GATT Article XXIV concerning the creation of customs unions and free-trade areas (FTAs)). Trade policy has been framed not only by the legal 'disciplines' but also by the common intersubjective understandings of the regime. DGI of the Commission thus describes the trade regime as 'the central' anchor of the Community's external role and applauds its 'implementation of the right policies'(WT O, [1997a]:12). M oreover, in the words of the Chairperson of a

5. The negotiations involved thirty nine countries and the EC proposed a linear cut of twenty percent in duties on manufactures, which was not adopted The outcome of the negotiations was the exchange of 4,400 tariff concessions consequent upon the creation of the customs union. 
WTO trade policy review meeting, 'the trade policies and actions of the EU do not leave any WTO member indifferent'(WTO, [1997b]:8).

The everyday economic role of the Community in the world system, and the role in which most countries have direct experience of the EC as an actor, is as gatekeeper of the Single $M$ arket and regulator of trade relations. It also now aspires to a more offensive role, as opener of overseas markets, under the Commission's $1996 \mathrm{M}$ arket Access Strategy. ${ }^{6}$ In acting out its role as gatekeeper, the Community benefits from its position at the centre of a complicated web of institutionalized bilateral links. They are provided for by Art. 310 of the Treaty of Rome (TEC), whereby the Community may establish 'an association involving reciprocal rights and obligations, common action and special procedures'. The common element in all these agreements is trade and, usually, some form of discrimination or preference. They are also increasingly 'trade plus' agreements which can include a great deal more than an agreed removal or realignment of tariffs. Association agreements, for example, include Association Councils, annual meetings at ministerial level plus Association Committees of senior civil servants, and there may even be a parliamentary element. From the earliest arrangements with Greece and Turkey the number and scope of agreements has increased markedly, especially since the 1980s, and re-negotiated 'second and third generation' agreements have further broadened the range of items covered. These now include elements of human rights and political conditionality, cultural and technical/ scientific cooperation and latterly the promotion of sustainable development. The coverage of such agreements is so extensive that the majority of states comprising the contemporary international system are now in some form of institutionalized preferential trade relationship with the EU. At the last count the EU had preferential (non M FN) agreements with no less than 117 states (Stevens, [1997]:1).

This very extensive network of preferential agreements would appear to violate the liberal and non-discriminatory principles of the international

6. This aims to achieve better access to third-country markets through a 'more focused, systematic and coordinated use of available trade instruments' So far this has involved the gathering of information on trade 'obstacles' but the Commission intention is to target particular countries (WTO, [1997a]:18). 
trade regime. The arrangements are, however, legitimized as either free trade areas (FTAs) or customs unions which are permitted under GATT Article XXIV. They also provide part of the foundation of another of the Union's significant roles - in which it can lay claim to being the largest development aid donor in the world. The key element of the EU's development role, the Lomé Convention, has enjoyed its own GATT waiver ${ }^{7}$ but it, and some of the other sustainable activities of the Union, as evidenced by the WTO dispute over its banana regime, are increasingly coming under challenge as an affront to free trade. The continuation of the Lomé arrangement is by no means cer tain and is currently subject to negotiation.

\section{A. Agriculture and Fisheries}

The historic counterpart of the creation of the common market was the Common Agricultural Policy (CAP). The basic mechanism of this policy, which sought to increase food production and raise farming incomes, ensured that there would also be external consequences. Artificially high prices within the EU were maintained by the imposition of a 'variable levy' on imports, which served to adjust their price up to the high level set for European produce while helping to fund the CAP's notorious production subsidies through intervention. When the Community sought alternatives to expensive stockpiling in the infamous 'wine lakes' and 'butter mountains' there was resort to export restitution payments, which made it possible to sell high-priced EU food on world markets. This merely added insult to injury as far as third party agricultural exporters were concerned. The U nited States, faced with the economic damage done to its farm exports, proceeded to retaliate with its own system of farm subsidies, further driving

7. As defined in GATT Art. XXIV(8), a customs union means the substitution of a single customs territory for two or more customs territories. As with the setting up of the EEC 'restrictive regulations of commerce' are removed within the union, while 'substantially the same duties and regulations' are applied by each member of the union towards outsiders (as in the Common External Tariff). A Free-Trade Area means 'a group of two or more customs territories in which duties and other restrictive regulations of commerce....are eliminated on substantially all trade between the constituent territories in products originating in such territories'. 
down world prices and worsening the terms of trade of those countries most dependent upon agricultural exports.

For a long time the EC was able to obstruct the subjection of the CAP to GATT disciplines, to the extent that it was often forgotten that the original GATT T reaty did not exclude trade in agricultural products. By this means the inherent contradictions between its GATT centred trade role and that of agricultural protectionist were held at bay. However, by the mid 1980s this separation was politically untenable. By the mid 1980s agricultural protection had become the central dispute between the US and the Europeans in the U ruguay Round.

To the role of agricultural protectionist one must add that of arbiter and protector of the Union's fisheries. A common fisheries policy had a basis in the Treaty of Rome, in that fish were defined as an agricultural product (TEC Art 38). However, it took until the early 1980s, under the stimulus of a worldwide extension of Exclusive Economic Zones to 200 miles from national coasts, to create a common policy for the management and marketing of the fish stocks in EC waters. Almost immediately, the number of fisherman and the tonnage of trawlers subject to the policy more than doubled with the accession of Spain and Portugal to the Community. Thus, the EU became a major player in the politics of world fisheries, signatory of no less than 26 bilateral fisheries agreements and most of the multilateral fisheries commissions. Continuous over-fishing and the desperate need to conserve stocks within EU waters has led to the controversial negotiation of access to African inshore fisheries.

While orthodox economic analysis of the EU'S activities in creating its own internal market and negotiating improved access could equate improved efficiency with environmental sustainability, the same cannot be said of the EU's agricultural and fisheries roles. The environmental effects of the CAP in terms of over use of intensive farming methods are well known and the external impact, in the view of two Commission officials, has been that the primary losers have been developing countries who have the misfortune to export non-tropical products (Paemen \& Bensch [1995]:24). Also, although the common fisheries policy has had to come to terms with its own European 'tragedy of the commons', one solution has been to increase the pressure on external fishing grounds. This is evident in the 
negotiation of access to African fisheries where indigenous sustainable fisheries have been imperilled. In the long run, given the serious state of global fisheries and their importance as a protein source in the South, there is an evident contradiction between the EU's development aspirations and the realities of its external fisheries policies, even though compensatory payments are made to the LDC governments involved. The external aspects of the common fisheries policy also directly contradict the sustainability objectives of both the Lomé Convention and the EU's own Treaty on European Union (TEU) (Eurostep [1995]:3). This is just one way in which the developing environmental role of the Union suffers from being grafted on to very well-established policies supported by important sectoral interest groups.

\section{B. The Union's E nvironmental Role}

In the beginning the Treaty of Rome was silent upon environmental matters. Significantly it required the 1972 Stockholm conference to persuade the leaders of the European Community, meeting in Paris, to take the first steps towards an environmental policy. Indeed, Sands ([1993]:545) regards $\mathrm{EC}$ environmental law as 'one of the most tangible outcomes of the Stockholm Conference'. But it is also probable that concerns about the trade implications of recently introduced German environmental legislation were equally significant (Somsen [1996]:183). The immediate result was the first Environmental Action Programme of 1973 (there have since been four more). It provided the impetus for the progressive adoption of over a hundred relevant policy instruments in the period up until 1987 (European Commission, [1990]:19). Areas in which extensive legislation, usually in the form of directives, has been adopted include: air and water quality, waste treatment, noise abatement, protection from hazardous chemicals and the conservation of wildlife and habitats. Originally action was based on specific directives and emissions controls. The current trend is to consolidate these into 'framework directives' (for air and water) and to adopt a more integrated and horizontal approach to the maintenance of environmental quality with increasing reliance upon 'market based' instruments such as ecolabelling and green taxes. ${ }^{8}$

The initial thrust of environmental policy was to remove trade distortions 
arising from different national standards and policies, although measures were also introduced with the sole purpose of promoting the conservation of the environment. ${ }^{9}$ The history of attempts to green the EU's internal market are of interest here because they may be transferable to the wider world trading regime and because they certainly influence EU external policy perceptions. In 1988 the European Court of J ustice (ECJ) decided in the celebrated case of the Danish bottles that, despite the Commission's complaints of violations of internal market rules, Denmark's environmental objectives were legitimate; and that the 'purpose of the legislation was the primary factor in determining the legitimacy of environmental regulations - with almost no regard to whether the means chosen to pursue a legitimate environmental interest burdened trade' (Esty, [1994]:263-4). However, such restraints on trade have not been generalized, neither have green taxes. Green taxation represents a particularly difficult area for the $E U$, because the Community does not have taxation powers and all attempts to provide for them, even when apparently necessitated by the single currency, have met with ferocious resistance from a number of $\mathrm{M}$ ember States (see for example the prolonged difficulties with carbon tax proposals designed to further the EU's contribution to the climate change regime). Instead the trend of policy has been towards attempting to harmonise national standards in packaging, waste disposal or vehicle emissions etc. This, theoretically at least, should prevent the use of environmental policy instruments that damage the free functioning of the internal market.

The Single European Act of 1987 (Title VII - Environment) accorded explicit treaty status to the Community's environmental objectives: to preserve protect and improve the quality of the environment, to contribute towards human health and to ensure a prudent and rational utilization of resources (TEC Art.174). Subsequent to this there has been a cascade of legislation, making the environment the area in which there was the great-

8. An important initiative in this regard is the IPPC or Integrated Pollution and Prevention Control, which provides for a system of controls and impact assessment which covers the whole range of pollutants and which is scheduled to come into force for new industrial installations in 1999.

9. The legal basis for the former was TEC Art94 and, for the latter, TEC Art.308. 
est increase in Community activity and in which national policies were increasingly determined at the European level (Sbragia, [1996]:243). This movement has only been strengthened by the Treaty on European Union 1992 (TEU) and the amendments agreed in the Treaty of Amsterdam, 1997, which make several new and prominent references to sustainable development as a Union objective intended to pervade all the Union's activities. As Weale ([1996]:598) observes, the EU's environmental policies 'go beyond any conceivable standards that would be strictly necessitated by a concern to ensure a single functioning market'.

The same dynamics that have driven the production of environmental policies at Union level also served to internationalize them. There are two main forces at work here. First, the pressure to respond to transboundary pollution and, increasingly, to global scale environmental changes; and, second, what may be broadly regarded as the trade implications of environmental policy. The need to respond to transboundary threats provided the impetus for the earliest major international negotiations in which the EU was engaged - the Transboundary Air Pollution (LRTAP) Convention of 1979 and its subsequent protocols relating to transboundary fluxes of nitrous and sulphuric oxides. These negotiations, involving over thirty $\mathrm{N}$ orth American and European states, were linked to those relating to acid rain deposition within the Community and the EU's own policies to combat acidification. An essentially similar point can be made about increasing involvement in marine pollution control, which physically must involve both M ember States and third parties in the N orth Sea and the M editerranean. The EU has also participated in negotiations relating to the sustainability of shared 'common pool' resources. Here, as we have seen, the Community has exclusive competence for the negotiation of fisheries agreements, both bilaterally and in such multilateral UN negotiations as those relating to 'Straddling Stocks'. The Community is also a signatory to the 1982 (in force from 1995) Third Law of the Sea Convention and of the 1982 Convention on the Conservation of Antarctic M arine Living Resources.

Direct interest in the global change phenomena, which achieved such prominence in the 1980s, is perhaps less immediately evident. In the case of stratospheric ozone depletion, the EU was slow to respond initially and beset by internal competence problems and the special interests of its 
chemical industries. However, European publics soon became aware that the dangers of UV/ B induced skin cancers and genetic mutations were not confined to the high latitudes of the Southern Hemisphere and the EU, had by the end of the 1980s, assumed a much more proactive stance.

Climate change issues associated with the enhanced greenhouse effect dominated the international environmental agenda during the early 1990s and there is little question that, despite an absence of Community competence for crucial energy and taxation questions, the $\mathrm{EU}$ has been at the forefront of climate diplomacy, particularly with its proactive stance in advance of the Kyoto Conference of the Parties of December 1997. The EC/EU has also been a participant in the other 'global change' Conventions on biodiversity and desertification.

The second source of internationalization derives from the fact that implementation of measures to counter environmental threats, or promote good practice at national (or at EU) level, will inevitably impact upon trade, investment and other flows across national boundaries. This, as we have seen, provided some of the motivation for the initial inclusion of environmental concerns in the EU's policy-making, and the need to ensure a 'level playing field' remains a major incentive for the Community to negotiate with third party states on environmental issues. Similarly, although there are genuine long-term concerns about climate change, the fact that energy questions vital to international competitiveness - are under discussion provides a very real short-run incentive to participate in the Climate Change Convention (FCCC). The 1992 Biodiversity Convention also has significant commercial implications. In consequence of all this activity, and much that has not been mentioned (for example the preservation of wildlife and endangered species), the Community is now a signatory to, and participates in at least thirty-one major multilateral environmental agreements (MEAs) (excluding their sometimes numerous protocols). In the politics of global environmental change the Union's representatives have quite self consciously claimed the mantle of leadership: whether in developing the climate change regime, strengthening the $\mathrm{M}$ ontreal Protocol, creating the Intergovernmental Panel on F orests, promoting the Basel Convention on hazardous waste or 'greening' the WTO (European Commission, [1997a]: 40,48,60,102). 


\section{Competence, Actorness and Decision-Making in Trade and Environment}

In examining the relationship between the trading and environmental roles of the European actor it is important to consider, albeit briefly, the institutional and policy-making framework in Brussels. This goes a long way to determine if and how the trade and environmental interests can be reconciled. There have been well known 'inconsistencies' and divergences of interest between $\mathrm{M}$ ember States in terms of their trading and agricultural interests. These date back to the Treaty of Rome and were so severe during the Uruguay Round that for, a long time, a vote in the Council of M inisters on the Blair House pre-Agreement was simply avoided. Trade policy conflicts are intersected by environmental policy differences between $\mathrm{M}$ ember States. This is hardly surprising in the light of their differing location, degree of modernisation and varying administrative traditions. It is also possible for large industrialised $\mathrm{M}$ ember States at similar levels of development to have fundamental policy differences. B ritish-German disagreement over the requirements for and approaches to pollution control provide a case in point (Weale, [1992]:66-92) . In general the Germans and Scandinavians have been 'pioneers' in the setting of high standards of environmental protection (Andersen \& Liefferink, [1997]).

The way such differences are handled will depend partly upon questions of 'coherence' within the Commission and also, of course, upon which of the EU's variety of decision-making procedures is employed and upon the location of competence. To deal first with the coherence question, there have been very clear differences in fundamental approach between the 'Relex' DGs concerned with external policy, and it has generally been acknowledged that the College of Commissioners has not been able to resolve them effectively. The Commission, for the purposes of the Common Commercial Policy, is DGI which, at least in relation to other DGs, has usually been associated with free-trading and an essentially liberal approach, especially under the leadership of Vice President Sir Leon B rittan. A member of DG VIII (Development) described this bluntly as 'la pensée unique' (Interview, 1997). Significantly, there is no formal Trade Council composed of national trade ministers within the regular schedule of Community business as there 
is, for example, an Agricultural or E nvironment Council. Instead the Council that deals with trade, alongside a great many other issues, is the General Affairs Council (GAC) composed of M ember State foreign ministers. They will benefit from a wider view of external policy (as opposed to what the Community defines as external relations) but they will not have the tightly focused sectoral interest in merchandise trade issues that the Agricultural Council will have with regard to the farming industry. The view of DG VI (Agriculture) is equally reflective of farming interests and traditionally protectionist. Both DG I and DG VI, whatever the differences between them, are larger, longerestablished and carry much greater weight in Brussels than DGXI, responsible for Environment,Nuclear Safety and Civil Protection.

There are also important differences between trade and environment in the extent to which the Community, as opposed to the M ember States, can be regarded as actors in international politics. Such differences have a legal basis in 'competence' - the EU term for 'powers' and to a certain extent in the recognition afforded to the Community by outsiders.

\section{A. Trade}

As the Common Commercial Policy developed, the Commission exhibited a significant degree of autonomy from the Member States, and a real capacity to behave in a deliberate way in relation to other actors. This is evident both from the legal ascription of competence and in actual practice, which has on occasion moved well beyond the 'letter of the law'. The legal foundation is provided by the exclusive competencein trade granted to the Community in the Common Commercial Policy established by Article 133 [ex 113] of the Treaty of Rome. This 'most frequently used Treaty provision in the exercise of the European Community's powers in the field of external relations' (M acleod, Hendry \& Hyett, [1996]:266) transfers the making and implementation of trade policy to the Community level, where there will be a common policy on tariff rates, international negotiations, liberalisation, exports and trade protection measures; all based on uniform principles. These were bound to be disputed because the wording of Article 133 is not 'exhaustive' in delimiting the categories of trade that are included within the 
Common Commercial Policy. The operative clause simply reads:

The common commercial policy shall be based on uniform principles, partic ularly in regard to changes in tariff rates, the conclusion of tariff and trade agreements, the achievement of uniformity in measures of liberalization, export policy and measures to protect trade such as those to be taken in the event of dumping or subsidies.

In the Common Commercial Policy (and also in agriculture) the Commission has the right to initiate policy and to propose negotiations, while the Council has the right to approve or disapprove acting by Q ualified M ajority Vote (QM V). Nevertheless, in the final analysis, where the national interests of $\mathrm{M}$ ember States are severely at risk, a de facto consensus may be required. In a negotiation the Commission will propose and the Council approve a mandate which provides the brief from which the Commission will actually conduct the talks.

The original 1947 GATT was an agreement between 'contracting parties' not an international organization. After the creation of the Community this gave rise to the anomaly that only the M ember State contracting parties had full legal status and responsibility for carrying out obligations, while at the same time, in terms of internal Community law, the EC had succeeded them as participants in the GATT (M acleod, Hendry \& Hyett, [1996]:179). Notwithstanding, the Commission exercised its exclusive competence in trade matters in the decision-making procedures of the regime - where the Community from the beginning has operated and been accepted as a single actor. A strong Commission presence was established in Geneva, the base of the GATT (and now WTO) Secretariat and Council meetings, where the Maison de l'Europe housed both the Commission's delegation and the ambassadors of the M ember States to the GATT. ${ }^{10}$ W ithin the GATT/ WTO

10. The significance of the GATT/WTO for the Community is also underlined by the fact that the only external representation of the Council General Secretariat is also in Geneva, where it services meetings of the 113 Committee and co-ordination meetings before specific WTO sessions (Interview) Furthermore, it was the Commission acting for the Community that signed the accession agreements of new GATT members and in the Tokyo Round was the sole party (excluding the individual M ember States) to most of the agreements made (M acleod, Hendry \& H yett, [1996]:289). 
context the Commission speaks on every issue and the M ember State representatives speak only upon budgetary questions. The situation has now been formalised by according the European Community full WTO membership in its own right. In the WTO the Community - in effect DGI of the Commission - is explicitly treated as 'a government'.

\section{B. E nvironment}

The Community gradually acquired competences for environmental policy but these were not exclusive but concurrent. The 1972 European Road Transport Agreement (ERTA) ruling provided that external competence in international dealings followed from the acquisition of internal competence. Subsequent to this, other ECJ rulings involved 'potential competence'. This extended ERTA principles to areas where, although there were no common rules in existence, participation of the Community in an international agreement 'is necessary for the attainment of one of the objectives of the Community'. ${ }^{11}$

As described in TEU Art.174(4) most environmental issues involve mixed agreements and concurrent competence, where representation is legally shared between Presidency and the Commission. For example, trade and air pollution issues in the stratospheric ozone negotiations gave the Community competence while other matters were reserved to M ember States. A relevant example is provided by $B$ asel Convention on hazardous waste. It has trade aspects where there is full Community competence, science and development assistance aspects where there is $\mathrm{M}$ ember State competence and environmental aspects where mixed competence prevails. M ixed competence leads to the confusing (at least for outsiders) situation where both the Commission and the Presidency will speak at different times in the same negotiation and, as with the experience of the M ontreal Protocol,

11. ECJ Opinion 1/ 76 (Rhine Navigation Case) This involved the negotiation of an agreement on a 'laying up fund' to deal with overcapacity in barges on certain waterways which necessarily involved Switzerland a non-member. The Court ruled that although there were no internal rules, the Commission nevertheless had implied external competence to negotiate because this was necessary to achieve EC Treaty objectives on transport. The law was further developed in the important context of the new trade issues included in the Uruguay Round in ECJ Opinion 1/ 94 (WTO). 
problems of internal EC/ EU coordination can interact with the talks proper. Thus, under mixed competence, the Union appears to be a less coherent actor; more closely resembling an alliance of states. However, even if there is limited Community competence, as with the climate change negotiations, there are numerous pressures that constrain the members of the Union to act together 'as 16' (fifteen $M$ ember States and the Commission). It is also worth mentioning that, whereas in the beginning external environmental policy could be hamstrung by the use of a M ember State veto in the Council, since the Single European Act Q ualified M ajority Voting has applied.

The actual development of the Community as a negotiating actor in the environmental field also depended upon what other participants were willing to accept. $N$ either were the $M$ ember States always willing to allow the separate representation of the Community. There have been continuing conflicts and disagreements as the Commission has sought to extend its external competence and provide the Community with a distinct voice in environmental diplomacy. In most M ultilateral Environmental Agreements (M EAs) concluded since the LRTAP the Community has been accorded Regional Economic Integration Organisation (REIO) status. This means that the Community can be party to a convention without any of its member states being a party. However, when one or more of the latter are also parties, 'the organization and its member states shall decide on their respective responsibilities for the performance of their obligations under the convention or protocol' (Vienna Convention 1985: Art.13(2)). Aside from this the Community has no automatic right of participation. Such rights have been negotiated on a case-by-case basis - and have been contested by M ember States. The Community has been recognised by the FAO, but virtually nowhere else does it have the status enjoyed at the WTO and certainly not within the UN General Assembly system, where it occupies an ambiguous position somewhere between an observer and a state government.

The implication is that the trading interest enjoys pre-eminence in a number of ways over the strictly environmental objectives of the Union. DGI, in conducting external trade relations, enjoys exclusive competence and has a symbiotic/ structurated relationship with the GATT/WTO. According to a national official, when issues are defined in terms of merchandise trade and pursued through the WTO policy tends to run along a set of 'tramlines' 
(Interview, London 1997). In the absence of a trade formation of the Council the national representatives on the 113 Committee share many of the assumptions of and enjoy a close working relationship with DGI. If, however, environmental policy is at issue (usually with trade aspects and implications) the EU can appear as a very different and less predictable actor. $M$ ixed or concurrent competence prevails, the Commission cannot necessarily initiate and 'lead states' can play a major proactive role in negotiation. In short the situation is much more open and fluid. How are these differences reflected in the actual trade/ environment policies of the Union?

\section{The E U and the Committee on Trade and the E nvironment}

EU spokespersons set a great deal of store by the Union's approach to the WTO Committee on Trade and E nvironment (CTE) which, since its establishment at $\mathrm{M}$ arrakesh, has become the focus of the specialised trade-environment debate. EU goals are described as 'ambitious' and disappointment is expressed that 'the sort of wide-ranging progress the EU had hoped to make' did not prove possible (WTO, [1997a]:15-16). In advance of the 1996 Singapore M inisterial a Commission Green Paper attempted to concentrate EU thinking on trade/ environment questions, leading to Council Conclusions adopted by the General Affairs Council in July 1996. The following principles were stressed:

* Trade and environmental protection can play a mutually supportive role in favour of sustainable development. Provided that effective environmental policies and sustainable devel opment strategies are implemented, trade makes possible a more efficient use of natural resources in both economic and envi ronmental terms. The conclusi on of the U ruguay Round of M ultilateral Trade $N$ egotiations has therefore been one of the most important recent contributions to the promotion of sustainable development.

* Environmental protection does not necessarily have a negative impact upon international competitiveness. Environmental policies can provide an incentive for technological innovation, promote economic efficiency and improve overall competitiveness. 
* Trade and environment issues must be approached in ways that do not jeopardize the sustainable development prospects of developing countries or undermine their overall export performance. Efforts should be made to enhance market access opportunities for environmentally friendly products from developing countries.

*The European Union should remain strongly committed to a multilateral approach to the most effective way to tackle global and transboundary environ mental problems. Furthermore, differences in environmental policies should not result in the introduction of environmental countervailing duties or other trade measures to protect domestic industry. (Commission [1997a],14).

These principles were reflected in specific approaches to the inconclusive CTE discussions - aiming to provide a 'green window' for the WTO. At the top of the agenda was discussion of the relationship between GATT rules and trade measures in multilateral environmental agreements (MEAs). The salience of this first item of the CTE's agenda is somewhat puzzling in that there has yet been no challenge to the relatively little used trade provisions of the various MEAs. The EC line, here, was that there should be either an explicit reference to the environment in $\operatorname{Art} X X(b)$ or an understanding on 'special treatment for trade measures under MEAs by virtue of which these measures would not have to pass the strict 'necessity test' of Art.XX' (B rit$\tan$ [1998]:21). While this was not achievable, attempts by some members to make Art.XX tests of MEA measures even more rigorous were resisted. According to former Trade Commissioner Sir Leon B rittan, 'We successfully averted these attempts and the final CTE report states, albeit in a careful manner, that the WTO is supportive of action at the multilateral level in order to address transboundary and global environmental problems (ibid.:22).

Under item 3 of the CTE Agenda the EC also proposed proper WTO recognition of eco-labelling based upon a life-cycle approach (LCA). This is a potentially very significant policy tool for environmentalists, who have 'underused the power of consumer driven market forces' (Esty [1994]:252). It was indeed the labelling of 'dolfin-friendly' tuna rather than disputed action under the US M arine Mammals Protection Act that drove 'dolfinunsafe' tuna off the US market in the early 1990s (ibid.). The EU and its 
more ecologically advanced $\mathrm{M}$ ember States have for some time been experimenting with eco-labelling, but - in so far as it is based upon life cycle rather than a 'like product' standard - it appears to many WTO members to violate GATT norms prohibiting discrimination on the basis of process and production methods (PPMS). Thus, although for EU commentators there is 'no reason why such schemes could not be consistent with existing or amended WTO rules provided they are non-discriminatory and do not constitute disguised restrictions upon trade' (Bail, [1996]:16), this view was not shared by the CTE as a whole. Nonetheless, the EC's intention is to press forward with eco-labelling and claim 'recognition under the TBT code or a code of conduct for these schemes' (B rittan, [1998]:22).

The third strand of EU policy at the CTE addressed item 6 on the relationship between trade liberalization and environmental protection. In the face of resistance from developing WTO members the legitimacy of specific environmental measures to accompany trade liberalization was pressed. According to the EU Trade Commissioner, this was one of the main green messages sent by the Commission to the Council and led to a satisfactory CTE outcome in which 'accompanying environmental measures are allowed when necessary to ensure the achievement of sustainable development' (ibid.:22).

While it is true that the trade-liberalizing stamp of DGI is more than evident here, and perhaps one could expect little else in a WTO for um, it is also true that the EU has attempted to 'green' the multilateral trading regime. The dissatisfaction at the 'logjam' in the CTE since the 1996 Singapore $M$ inisterial meeting is real enough. The EC is committed to an 'environment friendly interpretation of Art.XX', ending the 'anachronistic' neglect of the environmental implications of PPM $s$ and 'avoiding a fixed hierarchy between MTOs and WTO trade rules' (DGI online, EU, Trade and Environment, October 1998). It was even reported that at the $M$ ay 1998 Quad meeting which disagreed over the prospect for a new 'M illennium Round' Sir Leon B rittan declared that a failure to resolve 'apparent clashes between trade liberalization and environmental policies may impede progress in other areas'. The meaning of 'other areas' was interpreted at the time as the possibility that the WTO should take up the question of investment liberalization in the absence of a Multilateral Agreement on Invest- 
ment (www.icstd.org/ newsdigest, M ay [1998]).

\section{Beyond Trade - Prioritizing the Environment}

It is often held that, given the negative 'trade disarmament' type character of the GATT/ WTO, separate and specific environmental agreements are required. The WTO Secretariat has a view of the organization's competence that aligns directly with that of DGI:

WTO competence for policy co-ordination in this area is limited to trade and those trade related aspects of environmental policies which may result in signif icant effects for its Members. In other words, there is no intention that the WTO should become an environmental agency, not that it should become involved in reviewing national environmental priorities.. (WTO online, April [1997]).

Thus the active prohibition of dangerous and unsustainable trade has been left to other organizations. In these the EU can claim a leadership role, particularly in exporting its own internal market procedures (such as prior informed consent (PIC)). In 1992 the EU was the first to adopt legislation on the export and import of certain dangerous chemicals and has been in the forefront of negotiations to establish a binding PIC procedure for the movement of hazardous chemicals such as asbestos and pesticides across frontiers. The EU then went a good deal further, to the surprise of business interests (Amcham [1996]:45) in pressing for a total ban on the export of hazardous wastes from OECD to non-OECD countries. By mid-1998 the EC along with seven $\mathrm{M}$ ember States (including UK) were the only Parties, with the exception of Ecuador, to have ratified the ban (Krueger, [1998]:3). Although, from a business perspective:

Implementation of the B asel ban would effectively preclude global trade in valuable secondary raw materials. This would potentially have the impact of undermining $E U$ and $M$ ember State initiatives to promote the re-use recycling, and recovery of a wide range of waste streams....forcing devel oping countries to resort to primary raw materials .... and having long-term counter productive economic and environmental consequences. (Amcham, [ 1996]:45). 
Yet, as Krueger notes, environmentalists have 'characterised the 'Basel ban' as the most significant environmental achievement since the Rio Earth Summit of 1992' (1998:4). As was noted above, participation in the Basel Convention does not fall within the EC's exclusive trade competence and is led by DGXI.

\section{Trade before Environment - Some Failings of the Union}

There are a number of notable recent instances where the Union has fallen well short of its aspiration to green leadership. Two celebrated cases indicating the predominance of the trading interest- are considered below.

The Tuna-D olfin dispute was precipitated by a 1990 US ban on M exican tuna imports initiated by a private suit against the US government under the $M$ arine $M$ ammals Protection Act. The charge was that $M$ exico had failed to take adequate steps to reduce the number of E ast Pacific dolfin killed as a consequence of tuna fishing. M exico initiated a successful GATT disputes procedure on the grounds that the ban was both discriminatory and on the basis of process and production methods. The 1991 panel conclusions were never pressed to adoption by the GATT Council because M exico saw advantage in not complicating the construction of NAFTA.

At this point the EU entered the scene because French re-exports of processed M exican tuna to the US market also fell under the ban and EU exports of tuna in general had been affected - to the tune of 4 million ECU per annum (Lee [1998]:31). The basis of the EU case in 'T una Dolfin II 1994' was the illegality of the US ban in terms of its extraterritorial 'secondary embargo' and its unilateral character. The GATT panel found for the EU on the latter point. This reinforced what has been a key principle of EU policy - an unwavering insistence on multilateralism (see for instance the predicate of its proposals for emissions reductions in the Framework Convention on Climate Change.

Trade-related issues can cause serious policy inconsistency within the Commission itself and between the Council and Commission. A leading example is provided by the case of 'leghold traps, which pitted DGXI and the animal welfare lobby against DGI. The story begins with a 1991 Council Regulation (3254/ 91) which prohibited the use of leghold traps in the Com- 
munity and the introduction into the Community of furs originating in countries using leghold traps or other methods not meeting international humane standards. The intention was clearly to ban the import of furs from countries which had not outlawed the use of leghold traps (Canada, Russia and the USA). These barbaric instruments subject animals to a cruel and often prolonged death. In the original Regulation the Commission was clearly instructed to bring forward the relevant implementing measures. This it manifestly failed to do despite urgings from the animal welfare lobby and the E uropean Parliament. Thus, by 1st J anuary 1995, when the ban was supposed to become operative, the internal arguments were unresolved. They pitted Environment Commissioner Bjerrgaard against the formidable person of Commissioner Sir Leon Brittan. Arguing the adverse trade implications and possible reference to the GATT/ WTO disputes procedure, DGI was able to win the intra-Commission struggle to prevent the implementation of the ban, despite its prior agreement by the Environment Council.

The issue had now become a constitutional one for the EU and, of course, a question of whether free trade should always prevail over moral and environmental concerns. Following threats of legal action against the Commission by the European Parliament, and threats by the US government to initiate a WTO disputes procedure, the matter was resolved by the General Affairs Council, which recommended that a compromise deal be negotiated with the fur exporting countries. According to a 'senior Commission source' the deal would have 'enjoyed greater credibility if it was agreed by environmental ministers, but the most important thing is that it is agreed. This is better than a simple ban on leghold traps, with all its trade implications' (European Voice, 23-27 J uly [1997]).

\section{A. Trade, Gentically Modified Organisms and the E U}

No area of policy so exemplifies the contradictions between trade and environmental policy at the beginning of the twenty first century than that involving the new biotechnologies. For the EU and its trading partners the stakes are of a different order of magnitude to the contentious issues discussed above. For a long period EU institutions generally supported GM 0 technology as a means to more efficient agricultural production. Yet by 1999 
widespread public and commercial disquiet within Europe had led to a de facto EU ban on approvals of new genetically modified crops and calls by some $\mathrm{M}$ ember States at the June Environment Council for a full moratorium on imports of GM food. Even the previously pro-GM O government of the UK had introduced a labelling scheme. The US and other agricultural exporters regarded this as a form of protectionism clearly violating GATT rules, for there was little hard scientific evidence that GM Os caused environmental or health damage and relevant field trials were only in their infancy. The other side of the argument was that the application of import restrictions to GMOs and labelling of products with gentecially mofified constituents was merely a prudent appication of the precautionary principle.

At the international level the issue crystallised into the kind of incongruity between environmental and trade regimes that was the main item on the CTE agenda. During the late 1990s the Parties to the 1992 Convention on Biological Diversity (CBD) had been attempting to negotiate a Biosafety Protocol. The Protocol would establish the right of governments to regulate the import of 'living modified organisms' on environmental grounds and provided various mechanisms to this end including 'advanced informed approval'. While the EU took a moderate line at the Cartagena meeting of February 1999, which was to have agreed the final text of the Protocol, the US and its agricultural exporting allies in the M iami Group held out for minimal regulation and a Protocol oriented to trade facilitation rather than environmental protection. Despite EU efforts to broker a compromise the talks collapsed and it was widely expected, to the dismay of environmental activists, that the issue would be decided by default through being transferred to the WTO agenda. GATT/ WTO rules effectively disallow the exercise of the precautionary principle as a basis for the restraint of international trade.

Late in 1999 the issue surfaced at the ill-fated Seattle M inisterial M eeting of the WTO, which was attended not only by the Commission, led by the new trade Commissioner Pascal Lamy, but also by trade and environment ministers of the M ember States. The question of EU attitudes to GM Os had already soured transatlantic trade relations alongside the perennial matter of agricultural subsidies. Leading for the Union, Pascal Lamy agreed, in what appeared to be a deviation from the agreed EU position, that a WTO 
Working Group might be created to cover GM Os in the proposed 'M illennial Round'. In return for this concession the US agreed not to press its demands for further cuts in EU agricultural subsidies. The resulting public dispute within the EU delegation highlighted both the divergencies between the Union's agricultural and trade interests and its environmental policies, and the difficulties surrounding the Community's exclusive trade competence as exercised by DGI in WTO fora. Outraged members of the E nvironment Council apparently forced the Commisioner to retract at Seattle and in any event the proposals for Working Groups were declared to be 'dead' (Guardian 3 December 1999; Economist 11 December 1999:21; Independent 23 J anuary 2000. The unexpected agreement of the Biosafety Protocol, at the end of January 2000 is most unlikely to mark the end of the story - either for the members of the WTO or the institutions of the European Union.

\section{Conclusion}

There is now increasing alarm at the inadequacies and potential unsustainability of the global trade regime. The enormous trade and environmental presence of the European Union must make it a major player in attempts at greening the trade regime. Indeed, EU spokespersons have consistently claimed a leadership role. Understanding its potential in this respect requires a recognition that the $\mathrm{EU}$ constitutes a trade/ environment actor quite unlike any other. We have argued that its variable actor characteristics and roles are a significant determinant of its ability to influence events. There are contradictions between the various external policy roles that the Union has assumed, its capabilities as an actor and the extent to which it is recognised by third parties. What does this mean for the greening of the trade regime?

When the EU operates within the narrow focus of trade relations, any contradictions with environmental policies will tend to be resolved in favour of DGI - as has been graphically illustrated in the case of leghold traps. Equally, when environmental issues arise from strictly defined trade disputes, and there is reference to WTO procedures, any concern with environmental consequences will be subsidiary. On the other hand, the EC as a 
trade actor within the WTO has clearly been influenced by the sustainability requirements introduced into the Treaties since the Single European Act. Nevertheless, DGI has attempted to move the green agenda forward within the limited confines of the CTE. It seems likely, however, that serious difficulties will continue to arise in cases, such as that repesented by the dispute over GM Os, where environmental and trade or agricultural interests appear to conflict - and the level of stakes and public interest are high. Inevitably this will impact upon the ability of the EU to act coherently in external policy areas, and in particular to adopt the enviromental leadership role to which it has aspired.

\section{References}

Andersen, M.S. \& Liefferink, D. eds. [1997], E uropean Environmental Poli cy: The pi oneers, $M$ anchester, $M$ anchester University Press.

ACP-EC Development Finance Cooperation Committee [1997], Report and Resolution of the ACP-EC Finance Cooperation Committee, Brussels, ACP-CE 2144/ 7.

Allen, D, \& Smith, M . [1990], "Western Europe's Presence in the Contemporary International Arena," Review of International Studies 16(1); pp. 19-37.

Amcham [1996], B usiness Guide to EU Initiatives 1996, B russels, The EU Committee of the American Chamber of Commerce in Belgium.

Bail, A. [1996], "ECO-label, ECO-management and Environmental Reporting: A Challenge for Civil Society in a Global Economy" unpublished m.s.

Brack, D. ed. [1998], Trade and Environment: Conflict or Compatability?, London, Earthscan/ RIIA.

B retherton, C. \& Vogler, J. [ 1999], The European Union as a Global Actor, London, Routledge.

Brittan, L. [1998], "Trade and Environment after Singapore," in Brack ed.; pp. 27-48.

Esty, D.C. [1994], Greening the GATT: Trade, Environment and the F uture, Washington, Institute for International Economics.

European Commission [1990], Environmental Policy in the European Com - 
munity, Luxembourg, Office for Official Publications of the European Community.

European Commission [1997a], "For a Stronger and Wider Union," Agenda 2000 I, Strasbourg, DOC(97)6.

European Commission [1997b], Agenda 21, the First Five Years; European

Community Progress on the Implementation of Agenda 211992-97, Brussels.

European Commission [1997c], "Reinforcing the Pre-Accession Strategy," Agenda 2000 II, Strasbourg, DOC(97) 7.

Eurostep [1995], The Fight for Fish: Towards Fair Fisheries Agreements, Brussels, Eurostep.

FCO/DTI [1996], Free Trade and Foreign Policy : A Global Vision, London, Foreign and Commonwealth Office/ Department of Trade and Industry.

Krueger, J. [1998], The Basel Convention and Transboundary M ovements of Hazardous Wastes, Energy and Environment Programme, Briefing Paper N 0.45, London, RIIA.

Lee, J. [1998], "Trade-related Environmental M easures: How much is a Dolphin Worth?' in Brack ed.; pp. 27-48

M acleod, I., Hendry, T. \& Hyett, S. [1996], The External Relations of the European Communities: a Manual of Law and Practice, Oxford, Oxford University Press.

Paemen, H . \& Bensch, A. [1995], From the GATT to the WT O: the E uropean Community in the U ruguay Round, Leuven, Leuven University Press.

Ruggie, J.G. [1993], "Territoriality and B eyond: Problematizing M odernity in International Relations," International Organization 47(1); pp. 13974.

Sands, P.H. ed. [ 1993], The Greening of Internati onal Law, London, Earthscan.

Sbragia, A. [1996], 'Environmental Policy: The "Push-Pull" of Policy-M aking', in $\mathrm{H}$. Wallace \& W. Wallace (eds) Policy Making in the European Union, Oxford, Oxford University Press; pp. 235-55.

Somsen, H. [1996], "The E uropean Union and the Organization for Economic Cooperation and Development," in J. Werksman (ed) Greening International Institutions, London, Earthscan; pp. 181-204. 
Stevens, C. [1997], "How Substantial is EU Tariff Discrimination?," GEI Working Paper 31, U.K. Economic and Social Research Council.

Weale, A. [1992], The New Politics of Pollution, M anchester, M anchester University Press.

Weale, A. [1996], "Environmental Rules and Rule-M aking in the European Union," Journal of European Public Policy, 3:4, December; pp. 594-611. WTO [1997a], European Union: Report by the Secreatariat, http:/ / www.wto.org/ wto/ reviews.

WTO [1997b], Review of the European Union's TPRB Evaluation, http:/ / www/ wto/ org.wto.reviews. 